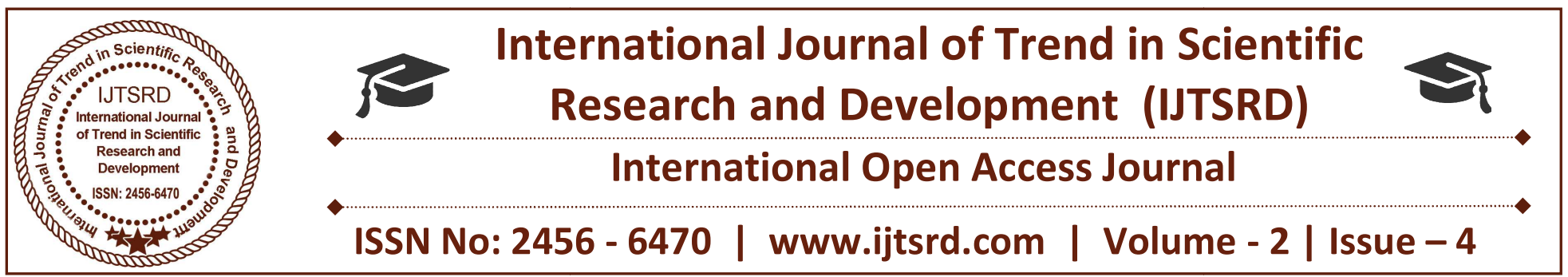

\title{
Optimization of Cutting Parameters in CNC Turning of AISI 304 \& AISI 316 Stainless Steel
}

\author{
Nethaji Perumal A ${ }^{1}$, Dr. B. Kumaragurubaran ${ }^{2}$, Dr. T. Senthil Kumar \\ ${ }^{1}$ P.G Scholar, M.E. (Manufacturing Engineering), ${ }^{2}$ Assistant Professor, ${ }^{3}$ Dean \\ 1,2,3 Mechanical Engineering Department, University College of Engineering, \\ ${ }^{1,2,3}$ BIT Campus, Anna University, Trichy, Tamil Nadu, India
}

\section{ABSTRACT}

This paper deals with finding optimal cutting parameters to get the better surface finish. It uses Taguchi method of experiments in arriving at optimal cutting speed, feed rate and depth of cut on turning operation. Turning is common method for cutting, especially for the finished machined products. Surface finish obtained in turning process depends upon so many factors like job material, tool material, tool geometry, machining parameters etc. This experimental study is carried out to find optimum parameters of CNC turning operation on AISI 304 and AISI 316 job materials using carbide coated tools.

Keywords: Turning Operation, AISI 304, AISI 316, Carbide coated tools, Optimum parameters, speed, feed, depth of cut, surface finish

\section{INTRODUCTION}

The modern industry goal is to manufacture high quality products in short time. CNC machines are capable of achieving high quality accuracy and very low processing time. Turning is common method for cutting, especially for the finished machined parts. In machining, surface quality is one of the most specified customer requirements. Surface finish in one of the main results of process parameters such as tool geometry and cutting condition (cutting speed, feed rate, depth of cut, etc.)
AISI 304 \& AISI 316 are considered as martensitic stainless steel and can be hardened like other alloy steels.

AISI 304 are widely used in aerospace industries for bearing, water valves, pumps, turbines, compressor components, shafting, surgical tools, plastic moulds nuclear applications etc. which demand high strength and high resistance to wear and corrosion.

Machinability is poor in turning AISI 304 because of low thermal conductivity, high ductility, high strength, high fracture toughness and rate of work hardening.

Coated carbides, boron carbides are basically a cemented carbide insert coated with one or more thinly layers of wear resistant material like Titanium CarboNitride. So in this investigation design of experiments employed for newly coated carbide tool on AISI 304 \& AISI 316 in CNC turning with coolant conditions.

\section{EXPERIMENTAL PROCEDURE}

The experimental procedure involves turning the jobs of AISI 304 and AISI 316 materials on CNC lathe using carbide coated tool. Parameters depth of cut, speed and feed rates will be varied to arrive at optimal parameters using Taguchi method. 
International Journal of Trend in Scientific Research and Development (IJTSRD) ISSN: 2456-6470

\section{A. Machine and materials considered}

Job material: (I) AISI 304

(II) AISI 316

Tool: Titanium Carbonitride coated tool

Machine: CNC lathe

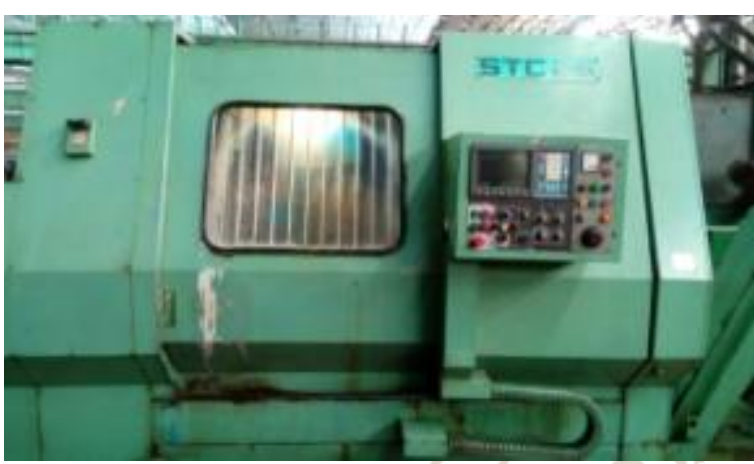

Fig 2.1 CNC Lathe

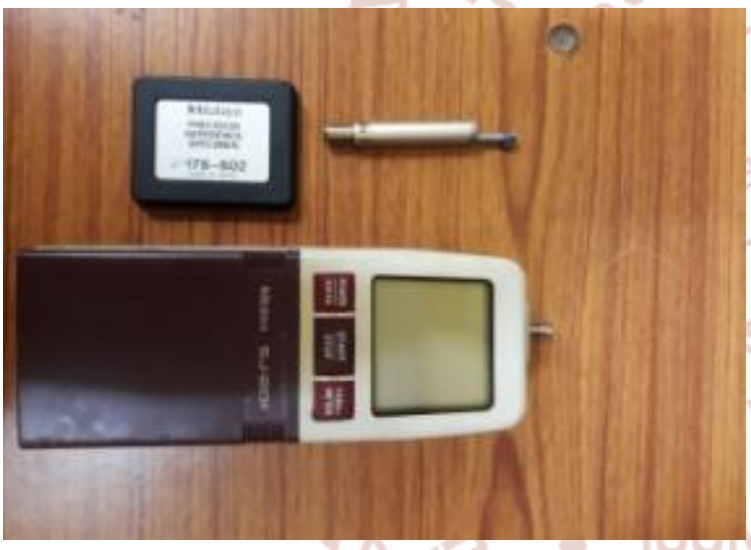

Fig 2.2 Surface roughness tester

\section{B. Methodology}

Step 1: Job will be fed in to the CNC lathe

Step 2: Selection of tool and parameters will be programmed

Step 3: Cutting Operation will be done

Step 4: Surface finish will be measured and recorded for each experiment

Step 5: Taguchi method is used to arrive at optimum parameters

\section{EXPERIMENTAL FUNCTION PARAMETERS}

AND

A. Objective Function
Since it is a turning operation, Taguchi smaller the better function is adopted.

Hence $\mathrm{S} / \mathrm{N}$ ratio as per Taguchi function is:

$n=-10 \log _{10}$ (mean of sum of squares of measured data)

$\mathrm{n}$ is $\mathrm{S} / \mathrm{N}$ ratio in decibels $(\mathrm{db})$

\section{B. Control factors and levels}

Table:3.1-Factors and levels

\begin{tabular}{|l|l|l|l|}
\hline \multirow{2}{*}{ Factors } & \multicolumn{2}{l|}{ Level } \\
\cline { 2 - 4 } & 1 & 2 & 3 \\
\hline Speed (S in RPM) & 600 & 900 & 1200 \\
\hline Feed(f in mm/Rev) & 0.1 & 0.15 & 2 \\
\hline Depth of cut(D in mm) & 0.4 & 0.8 & 1.2 \\
\hline
\end{tabular}

IV. EXPERIMENTAL RESULTS

\section{A. For AISI 304}

Table 4.1 Surface finish for AISI 304

\begin{tabular}{|l|l|l|l|l|}
\hline $\begin{array}{l}\text { S1 } \\
\text { No }\end{array}$ & $\begin{array}{l}\text { Speed } \\
(\text { RPM })\end{array}$ & $\begin{array}{l}\text { FEED } \\
(\mathrm{mm} / \text { Rev })\end{array}$ & $\begin{array}{l}\text { DEPTH } \\
\text { OF CUT } \\
(\mathrm{mm})\end{array}$ & $\begin{array}{l}\text { SURFACE } \\
\text { FINISH } \\
(\mu \mathrm{m})\end{array}$ \\
\hline 1 & 600 & 0.1 & 0.4 & 0.72 \\
\hline $2 \mathrm{~m}$ & 600 & 0.15 & 0.8 & 0.8 \\
\hline 3 & 600 & 0.2 & 1.2 & 2.06 \\
\hline 4 & 900 & 0.1 & 0.8 & 0.85 \\
\hline 5 & 900 & 0.15 & 1.2 & 1.3 \\
\hline 6 & 900 & 0.2 & 0.4 & 0.63 \\
\hline 7 & 1200 & 0.1 & 1.2 & 0.78 \\
\hline 8 & 1200 & 0.15 & 0.4 & 0.55 \\
\hline 9 & 1200 & 0.2 & 0.8 & 1.08 \\
\hline
\end{tabular}

RPM-Rotations per minute; mm-millimeter; $\mu \mathrm{m}$-Micrometer;Rev-Revolution

B. For AISI 316

Table 4.2 Surface finish for AISI 316

\begin{tabular}{|l|l|l|l|l|}
\hline $\begin{array}{l}\text { Sl } \\
\text { No }\end{array}$ & $\begin{array}{l}\text { Speed } \\
(\text { RPM })\end{array}$ & $\begin{array}{l}\text { FEED } \\
(\mathrm{mm} / \mathrm{Rev})\end{array}$ & $\begin{array}{l}\text { DEPTH } \\
\text { OF } \\
\text { CUT } \\
(\mathrm{mm})\end{array}$ & $\begin{array}{l}\text { SURFACE } \\
\text { FINISH } \\
(\mu \mathrm{m})\end{array}$ \\
\hline 1 & 600 & 0.1 & 0.4 & 0.9 \\
\hline 2 & 600 & 0.15 & 0.8 & 1.06 \\
\hline 3 & 600 & 0.2 & 1.2 & 2.29 \\
\hline 4 & 900 & 0.1 & 0.8 & 0.88 \\
\hline 5 & 900 & 0.15 & 1.2 & 1.42 \\
\hline
\end{tabular}


International Journal of Trend in Scientific Research and Development (IJTSRD) ISSN: 2456-6470

\begin{tabular}{|l|l|l|l|l|}
\hline 6 & 900 & 0.2 & 0.4 & 0.86 \\
\hline 7 & 1200 & 0.1 & 1.2 & 0.95 \\
\hline 8 & 1200 & 0.15 & 0.4 & 0.63 \\
\hline 9 & 1200 & 0.2 & 0.8 & 1.41 \\
\hline
\end{tabular}

b. Feed

$\sum_{\mathrm{f} 1}=\mathrm{n} 1+\mathrm{n} 4+\mathrm{n} 7$

$\sum_{\mathrm{f} 2}=\mathrm{n} 2+\mathrm{n} 5+\mathrm{n} 8$

RPM-Rotations per minute; mm-millimeter; $\mu \mathrm{m}$-Micrometer;Rev-Revolution

\section{EXPERIMENTAL DATA ANALYSIS}

By using Taguchi $\mathrm{S} / \mathrm{N}$ ratio objective function the following data was obtained

$\sum_{\mathrm{f} 3}=\mathrm{n} 3+\mathrm{n} 6+\mathrm{n} 9$

Average $\mathrm{S} / \mathrm{N}$ ratio $=\left(\sum_{\mathrm{f} 1}+\sum_{\mathrm{f} 2}+\sum_{\mathrm{f} 3}\right) / 3$

\section{c. Feed}

$\sum_{\mathrm{D} 1}=\mathrm{n} 1+\mathrm{n} 6+\mathrm{n} 8$

$\sum_{\mathrm{D} 2}=\mathrm{n} 2+\mathrm{n} 4+\mathrm{n} 9$

\section{A. For AISI 304}

$\sum \mathrm{D} 3=\mathrm{n} 3+\mathrm{n} 5+\mathrm{n} 7$

Table 5.1: Calculated S/N Ratios for AISI 304

\section{Average $\mathrm{S} / \mathrm{N}$ ratio $=\left(\sum_{\mathrm{D} 1}+\sum_{\mathrm{D} 2}+\sum_{\mathrm{D} 3}\right) / 3$ \\ C. For AISI 304}

Table 5.3: Factor ranking for AISI 304

\begin{tabular}{|l|l|l|l|l|l|l|}
\hline \multirow{2}{*}{$\begin{array}{l}\text { Le } \\
\text { vel }\end{array}$} & \multicolumn{2}{|l|}{ Speed } & \multicolumn{2}{l|}{ Feed } & \multicolumn{2}{l|}{ Depth of Cut } \\
\cline { 2 - 7 } & $\sum_{\mathrm{s}}$ & $\mathrm{Avg}$ & $\sum_{\mathrm{f}}$ & Avg & $\sum_{\mathrm{D}}$ & Avg \\
\hline 1 & -1.48 & -0.49 & 6.42 & 2.14 & 12.05 & 4.01 \\
\hline 2 & 3.14 & 1.04 & 4.85 & 1.61 & 2.68 & 0.89 \\
\hline 3 & 6.68 & 2.22 & -2.93 & -0.97 & -6.39 & -2.13 \\
\hline
\end{tabular}

\section{B. For AISI 316}

Table 5.2: Calculated S/N Ratios for AISI 316

\begin{tabular}{|l|l|}
\hline Sl NO & $\mathrm{n}(\mathrm{db})$ \\
\hline 1 & 0.915 \\
\hline 2 & -0.506 \\
\hline 3 & -7.197 \\
\hline 4 & 1.11 \\
\hline 5 & -3.046 \\
\hline 6 & 1.31 \\
\hline 7 & 0.446 \\
\hline 8 & 4.013 \\
\hline 9 & -2.984 \\
\hline
\end{tabular}

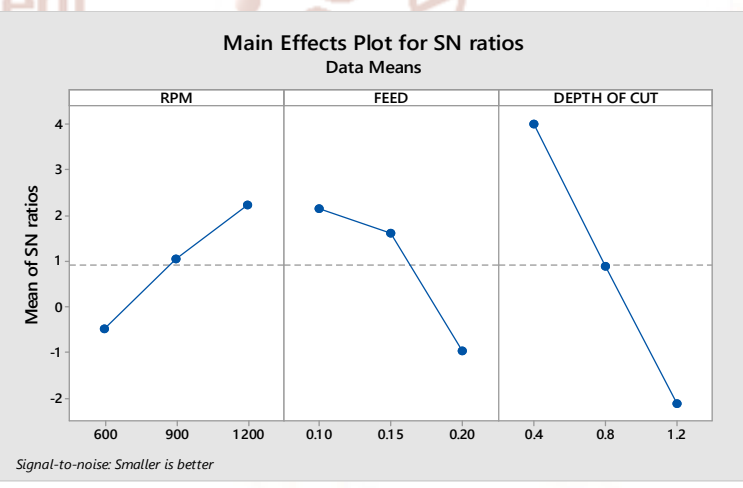

Fig 5.1 Signal to noise ratio for AISI 304

Individual factors $\mathrm{S} / \mathrm{N}$ ratio is calculated by using these functions:

\section{a. Speed}

$\sum_{\mathrm{s} 1}=\mathrm{n} 1+\mathrm{n} 2+\mathrm{n} 3$

$\sum_{\mathrm{s} 2}=\mathrm{n} 4+\mathrm{n} 5+\mathrm{n} 6$

$\sum_{\mathrm{s} 3}=\mathrm{n} 7+\mathrm{n} 8+\mathrm{n} 9$

Average $\mathrm{S} / \mathrm{N}$ ratio $=\left(\sum_{\mathrm{s} 1}+\sum_{\mathrm{s} 2}+\sum_{\mathrm{s} 3}\right) / 3$ 
International Journal of Trend in Scientific Research and Development (IJTSRD) ISSN: 2456-6470

D. For AISI 316

Table 5.4: Factor ranking for AISI 316

\begin{tabular}{|l|l|l|l|l|l|l|}
\hline \multirow{2}{*}{ Level } & \multicolumn{2}{l|}{ Speed } & \multicolumn{2}{l|}{ Feed } & \multicolumn{2}{l|}{$\begin{array}{l}\text { Depth of } \\
\text { Cut }\end{array}$} \\
\cline { 2 - 7 } & $\sum_{\mathrm{s}}$ & Avg & $\sum_{\mathrm{f}}$ & Avg & $\sum_{\mathrm{D}}$ & Avg \\
\hline 1 & - & - & 2.47 & 0.82 & 6.23 & 2.07 \\
\hline 2 & $\begin{array}{l}-67 \\
0.62\end{array}$ & 0.20 & & & & \\
\hline 3 & 1.47 & 0.49 & -8.87 & - & - & -3.26 \\
& & & & 2.95 & 9.79 & \\
\hline
\end{tabular}

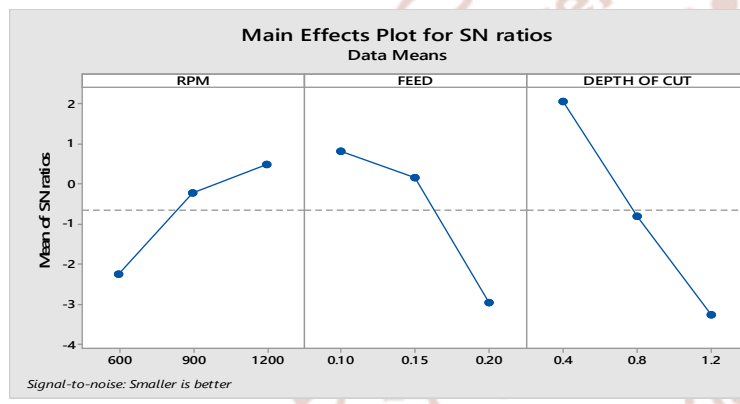

Fig 5.2 Signal to noise ratio for AISI 316

\section{CONCLUSION}

In this experiment, We have conducted the turning operation of various parameter combinations by using Taguchi method and the following are the conclusions:

- For AISI 304, optimum parameters to achieve good surface finish by using Titanium Carbonitride coated tool is of around 1200 RPM speed, feed rate of around $0.1 \mathrm{~mm} / \mathrm{rev}$ and $0.4 \mathrm{~mm}$ depth of cut

- For AISI 316, optimum parameters to achieve good surface finish by using Titanium Carbonitride coated tool is of around 1200 RPM speed, feed rate of around $0.1 \mathrm{~mm} / \mathrm{rev}$ and $0.4 \mathrm{~mm}$ depth of cut

- From the above experiments, In general Good surface finish is proportional to speed and inversely proportional to depth of cut and feed rate.

\section{REFERENCES}

1. Salah Gasim Ahmed (2006) "Development of a Prediction Model for Surface Roughness in Finish Turning of Aluminium", Sudan Engineering Society JOURNAL, January 2006, Volume 52 No.45

\section{OPTIMUM FACTORS}

From the ranking table, The optimal parameter is arrived.

\section{A. For AISI 304}

Table 6.1: Optimal parameters values for AISI 304

\begin{tabular}{|l|l|}
\hline Factor & Value \\
\hline Speed (S in RPM) & 1200 \\
\hline Feed(f in mm/Rev) & 0.1 \\
\hline Depth of cut(D in $\mathrm{mm})$ & 0.4 \\
\hline
\end{tabular}

\section{B. For AISI 316}

Table 6.2: Optimal parameters values for AISI 316

\begin{tabular}{|l|l|}
\hline Factor & Value \\
\hline Speed (S in RPM) & 1200 \\
\hline Feed(f in mm/Rev) & 0.1 \\
\hline $\begin{array}{l}\text { Depth of cut } \\
(\mathrm{D} \text { in } \mathrm{mm})\end{array}$ & 0.4 \\
\hline
\end{tabular}

2. Onyemachi Joachim Onuoha, James Oseni Abu, Sunday Albert Lawal, EdekiMudiare, Michael BolajiAdeyemi (2016)"Determining the Effect of Cutting Fluids on Surface Roughness in Turning AISI 1330 Alloy Steel Using Taguchi Method", Modern Mechanical Engineering, 2016, 6, 51-59

3. G J Pavan Kumar and R LalithaNarayana (2015)"Prediction of Surface Roughness In Turning Process Using Soft Computing Techniques",International Journal of mechanical and robotics research, Jan 2015

4. Andrew A. Erameh, Nurudeen A. Raji, Rasheed O. Durojaye, Abiodun A. Yussouff (2016) "Process Capability Analysis of a Centre Lathe Turning Process", Engineering, 2016,8, 7985

5. Arunkumar. G $\mid$ Dr. P. Navaneetha Krishnan "Experimental Enhancement of Heat Transfer Analysis on Heat Pipe using $\mathrm{SiO} 2$ and TiO2 Nano Fluid" Published in International 
Journal of Trend in Scientific Research and Development (ijtsrd), ISSN: 2456-6470, Volume2 | Issue-4 , June 2018

6. B.Tulasiramarao, Dr.K.Srinivas ,Dr. P Ram Reddy, A.Raveendra, Dr.B.V.R.Ravi Kumar (2015)"Experimental Study On The Effect Of Cutting Parameters On Surface Finish Obtained In CNC Turning Operation", International Journal of Innovative Research in Science,Engineering and Technology, Sep 2015

7. H.Oktema,T. Erzurumlu, H. Kurtaran (2005)"Application of response surface methodology in the optimization of cutting conditions for surface roughness", Journal of Materials Processing Technology 170 (2005) 1116

8. Saurav DATTA, SibaSankar MAHAPATRA (2010)"Simultaneous Optimization of Correlated Multiple Surface Quality Characteristics of Mild Steel Turned Product",Intelligent Information Management, 2010, 2, 26-39
9. N. Fang, P. SrinivasaPai, N. Edwards (2016) "Neural Network Modeling and Prediction of Surface Roughness in Machining Aluminum Alloys", Journal of Computer and Communications, 2016, 4, 1-9

10. Kalyanmoy Deb and Ram BhushanAgrawal(1995) "Simulated Binary Crossover for Continuous Search Space", Complex Systems 9 (1995) 115148

11. P.G Benardos, G.C Vosniakos (2012) "Prediction of surface roughness in $\mathrm{CNC}$ face milling using neural networks and Taguchi's design of experiments", International Journal of Advanced Engineering Research and Studies E-ISSN2249$8974,2012 / 47-50$

12. Yalcin M. Ertekin , Yongjin Kwon, Tzu-Liang (Bill) Tseng (2003) "Identification of common sensory features for the control of $\mathrm{CNC}$ milling operations under varying cutting conditions", International Journal of Machine Tools \& Manufacture 43 (2003) 897-904 